insteat of "Alise of plate gliss." which is an entirely different eontrit. ance. We have detected a few gemuine printer's emors, vize pre-nol for per-oral, deglutatery for deglutitcry, and the peference on p. 1:21 1., Fig. f.5, which shonld reat Fig. 4t, and perhaps therertom!y for thom cofom!l comes moler this hemt.

"J)irect Larrngosenps, Bronchoseopy and (Esophlanguseopy" is an

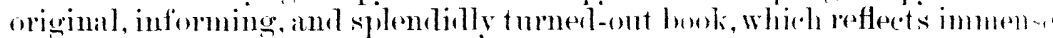
credit upen anthor, transhator and publishers.

Irillirm Mill.

\title{
THE TEACHING OF OTO-LARYNGOLOGY IN ITALY.
}

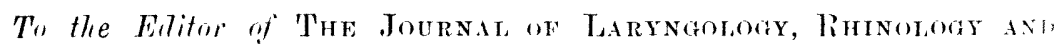
()TOLOAS.

Dear Sin,-- In an article by Prof. Massei, published in the Jourci. of Rakyngologr, Rhinology and Otologr, April, 1912. on the (on ditions of miversity teaching of Oto-rhino-laryngology in Italy, it is staten that, except in Rome, there exist no other clinies of this speciality with hort. Now, while this is correst as regards Naples and some of her muiversitir. of the kingilom, it is not trute for Turin. In Turin there has heen in existences ever since 1895 a university clinic with tem beds moler the direction of the undersigned. In orter to aid the official clinie the mmlersigned fommled in 1900 a private clinic, which at present contain. seventy lests, and which allows him in the most efficacions manner to itrange for the teaching both of students ind of doctors. At Genon, Parvi: aml Padua also, although a real clinic has not ret been instituted, th. Professors Masini. Nieclai and Arslan have the disposal of a number w heals sufficient to serve for their teaching. Althomgh, however, in Italy, at in other countries, ()to-rhino-largagology has not yet reached the height which is due to its importance in meidical stulies, the progress mirle during these last vears fills us with confidence that a better fouture alwaits it.

'T'URIN ;

$M(1 y !), 1912$.

Yours truly,

Prof. Jir. G. Granentao,

Ordinary in the Unirersity of 'Turiu

\section{BOOKS RECEIYED.}

Handbuch der speciellen Chirurgie des Ohres und der Oberen Luftwege

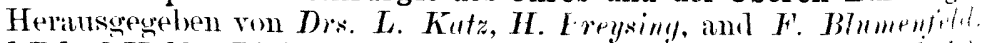
1 Bil., 2 Hälfte, Lief. ti. Würzburg: Verlag von Curt Kabitsch, igl:..

Die neue Wiener Klinik fur Kehlkopf und Nasenkrankheiten. Yin

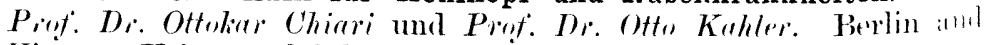
Vienna: Urban und Schwarzenberg. 1912.

The Skiagraphy of the Accessory Nasal Sinuses. By A. Loyfan Turnt' M.I)., F.R.C.S.E., F.R.S.F., and W.G. Porter, M.S., I Sc., F.R.C.. L.

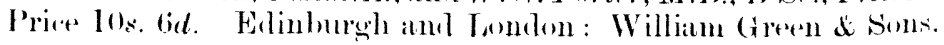

